Article

\title{
Sustainable Entrepreneurial Orientation in Family Firms
}

\author{
Felipe Hernández-Perlines ${ }^{1, *}$ (D) and Nina Rung-Hoch ${ }^{2}$ \\ 1 Department of Business Administration, University of Castilla-La Mancha, Toledo 45071, Spain \\ 2 Department of Strategy, Leadership and People, Barcelona 08021, Spain; Nina.rung_hoch@euruni.edu \\ * Correspondence: Felipe.HPerlines@uclm.es; Tel.: +34-925-268-800
}

Received: 19 June 2017; Accepted: 4 July 2017; Published: 10 July 2017

\begin{abstract}
This study examines how an entrepreneurial orientation moderates the effect of corporate social responsibility (CSR) on family firm performance. Analysis of 174 family firms was conducted using second-generation, partial least squares structural equation modeling (PLS-SEM) in SmartPLS 3.2.6. A survey of family firms and compliant sustainability reports, made under the rules of the GRI (Global Reporting Initiative) for these firms yielded the empirical data. This study contributes to the literature in several ways. First, the analysis shows that GRI reports offer a suitable way for analyzing CSR because the proposed measures are reliable and valid. Second, CSR actions by family firms exert a substantial positive influence on these firms' performance. Third, entrepreneurial orientation is a good predictor of the success of family firms, positively influencing their performance. Fourth, entrepreneurial orientation positively moderates the effect of CSR on family firm performance, enhancing this effect.
\end{abstract}

Keywords: sustainable entrepreneurial orientation; firm performance; family firms; moderating effect; PLS

\section{Introduction}

In recent years, corporate social responsibility (CSR) and entrepreneurial orientation have been the focus of numerous studies in the business literature. CSR is also a priority for companies and their management teams [1,2] and lies at the heart of firms' business activities because of its ability to create shared value [3]. CSR is a key factor for achieving sustainable economic growth through greater social cohesion [4]. Accordingly, sustainable development encompasses economic, social, and environmental goals [5]. Similarly, entrepreneurial orientation is considered a valuable predictor of business success [6] because of its influence on business performance [7-13] and its capacity to create value [14]. From a macroeconomic perspective, entrepreneurial orientation is capable of improving the economy [15] through the creation of wealth and employment [16], and it encourages competition in an increasingly global business environment [15]. Entrepreneurial orientation is so important that it may be considered a priority for many governments [17].

Although CSR is a potential source of competitive advantage [18] that positively influences firms' performance [19-22], certain business behaviors may act as moderators in this relationship. Hence, the research questions that are addressed in this study justify the study's relevance. We analyzed the way entrepreneurial orientation moderates the effect of CSR on business performance. The entrepreneurial strategies adopted by a firm can shape the actions it takes in response to environmental pressures [23], allowing the firm to take steps toward sustainability [24]. The theoretical model that we used to analyze the relationship between CSR and business performance was proposed by Preston and O'Bannon [25]. Adopting a neutral approach for this model allowed us to consider the moderating effects of certain variables. We analyzed the moderating effect of entrepreneurial orientation in similar 
terms to the way that other moderating effects have been addressed in other studies (e.g., sales [26] and competitive strategy [27]). Traditionally, entrepreneurship has been analyzed in terms of its relationship with economic development [28,29]. Recently, however, studies have emerged that link entrepreneurship to sustainable development [30-33]. This study advances our understanding of what is known as sustainable entrepreneurship, which consists of introducing new products and new business practices that are linked to CSR [24]. This social entrepreneurship leads to the emergence of sustainable businesses [30,34-36], which create value differently from the way it has traditionally been created [37]. The scarcity of empirical studies that examine sustainable entrepreneurship [38,39] justifies this study's relevance and represents a research opportunity.

This study focuses on family firms because they are a key driver of growth and well-being. In Spain, family firms account for $89 \%$ of active businesses, $57 \%$ of Spanish GDP, and $67 \%$ of private-sector employment [40].

\subsection{Corporate Social Responsibility (CSR)}

Companies must develop ways to compete in an expanding, ever-changing market. Analyses of what affects business performance are therefore necessary to foster positive factors and curb the effects of negative factors. Accordingly, CSR has become a priority for companies and managers [41]. Although analysis of CSR dates back to the early 20th century [42,43], it did not become popular until the emergence of stakeholder theory [44]. Today, CSR is at the heart of many firms' activities, because of its ability to create shared value for businesses and society [3].

CSR studies have yielded mixed results regarding CSR's influence on business performance, with studies showing that CSR may have a positive, negative, or neutral effect on performance [41,45-47]. Research into CSR in family firms is a recent development in the business literature [48]. The literature contains two major blocks of research on CSR in family firms:

(1) The first block of research comprises studies that focus on comparative analyses of the different approaches to CSR in family and non-family firms [32,49-51]. The nature of family firms affects their behavior toward stakeholders [52-55]. Specifically, family firms are more likely to act in the interests of their stakeholders [56] because the behavior of family firms is simultaneously driven by financial and non-financial goals [52].

(2) The second block of research comprises studies that focus on heterogeneity across family firms. Most of the studies try to analyze how the responsible behavior of the family companies improves their competitive position [57]. De la Cruz Déniz Déniz and Cabrera Suárez [58] analyzed the value system of family firms and the CSR actions they develop. Ding and Wu [59] found that the youngest family firms were concerned less with CSR than with socio-emotional wealth. Finally, some empirical studies have tried to link social responsibility and financial performance in family firms [60-62].

There are numerous definitions of CSR. For this study, we defined CSR as the information that is published in sustainability reports that inform stakeholders and society about the firm's actions in economic, social, and environmental spheres [63,64].

The idea that underlies our first hypothesis is that CSR is a source of competitive advantage [18] and therefore positively influences business performance [19-22,65,66]. Rather than limiting performance, sustainability efforts based on CSR actually offer firms an opportunity to grow and develop [67].

Sustainable performance comprises three dimensions that are crucial for firms: the economic dimension, the social dimension, and the environmental dimension [68,69]. Firms wishing to discover new business opportunities must adopt a systemic approach to sustainability [70]. Sustainability management offers a way for firms to differentiate themselves as part of their strategic processes [71-75]. We therefore propose the following hypothesis:

Hypothesis 1 (H1). CSR positively affects the performance of family firms. 


\subsection{Entrepreneurial Orientation}

Considered highly relevant in a range of social and economic contexts [23], entrepreneurial orientation has become a key topic in business literature and has led to the creation of extensive knowledge [76-80]. Entrepreneurial orientation has been redefined many times since its original conception. The first scholar to discuss entrepreneurial orientation was Miller [7], who described entrepreneurial orientation as business behavior that is characterized by innovativeness, proactiveness, and risk-taking [7]. Scholars have since honed this definition, indicating that entrepreneurial orientation depends on the extent to which change and innovation, risk-taking, and competitive aggressiveness are encouraged $[10,81]$. But entrepreneurial orientation can also be linked to the firm's capability to undertake activities related to innovation, risk-taking, and pioneering new actions [79]. Entrepreneurial orientation must be understood as a decision-making process that affects the firm's will to innovate, outdo competitors in terms of proactiveness and aggressiveness, and take risks [82]. In short, entrepreneurial orientation involves the discovery, evaluation, and exploitation of opportunities to introduce new products or services to the market [15].

For this study, we defined entrepreneurial orientation as a second-order composite consisting of innovativeness, proactiveness, and risk-taking [7]. Innovativeness refers to the firm's ability to support new ideas and experiment, introduce new products, and use creative processes [82-84]. Proactiveness is the firm's capability to use resources to introduce new products and services ahead of competitors [10,77]. Risk-taking means undertaking daring actions that use considerable resources [6]. In these dimensions, and therefore in entrepreneurial orientation, purposeful action by managers plays a central role [16].

Entrepreneurial orientation in family firms has also been addressed by scholars. So Naldi et al. [85] report that risk-taking in family firms is an important dimension that differs from entrepreneurial orientation and that is positively associated with proactiveness and innovativeness yet negatively related to performance. Casillas and Moreno [86] analyzed how the environment (through the dimensions of dynamism and hostility) moderates the way the generation of the family firm, the presence of non-family managers, and the presence of the next generation of the family at the management level affect entrepreneurial orientation (in terms of innovativeness, proactiveness, and risk-taking). Casillas and Moreno [86] report that environmental dynamism has a significant moderating effect on the relationship between the presence of the next generation of the family at the management level and entrepreneurial orientation (innovativeness, proactiveness, and risk-taking). Similarly, they report that environmental hostility positively affects proactiveness and risk-taking but not innovativeness. Nordqvist and Melin [87] analyzed the actors, activity, and entrepreneurial orientation of family firms. Weismeier-Sammer [88] concluded that size influences the entrepreneurial behavior of family firms. According to Zellweger and Sieger [89], entrepreneurial orientation is dynamically adapted in long-lived family firms. For Cruz and Nordqvist [90] the generation of the family firm affects the correlation between external factors (the perceptions of the competitive environment), internal factors (the presence of non-family managers), and entrepreneurial orientation. Vecchiarini and Mussolino [91] report that the presence of family members at the management level and the professionalization of the management influence entrepreneurial orientation. Garcés-Galdeano et al. [92] report that socioemotional factors influence the entrepreneurial orientation of family firms. Only Kellermanns et al. [93] note that the entrepreneurial orientation of family firms is an important success factor. Finally, Schepers et al. [94] report that entrepreneurial orientation improves family firms' performance, highlighting the role of socioemotional elements in the relationship.

Studies have shown the existence of a positive relationship between entrepreneurial orientation and firm performance $[7,10,13,95]$. In addition to containing studies showing a direct, positive relationship, the literature also contains studies that analyze the mediating [96-99] and moderating effects of entrepreneurial orientation [100-103].

The analysis in this study is a response to the following research question: Can entrepreneurial orientation moderate the relationship between CSR and the performance of family firms? As previously 
explained, analyzing the moderating role of entrepreneurial orientation is a novel approach in the context of CSR and family firm performance. We therefore propose the following hypothesis:

Hypothesis 2 (H2). Entrepreneurial orientation moderates the effect of CSR on family firm performance.

The theoretical model in Figure 1 illustrates the hypotheses that we propose based on the literature review. This model captures the moderating effect of entrepreneurial orientation on the relationship between CSR and family firm performance.

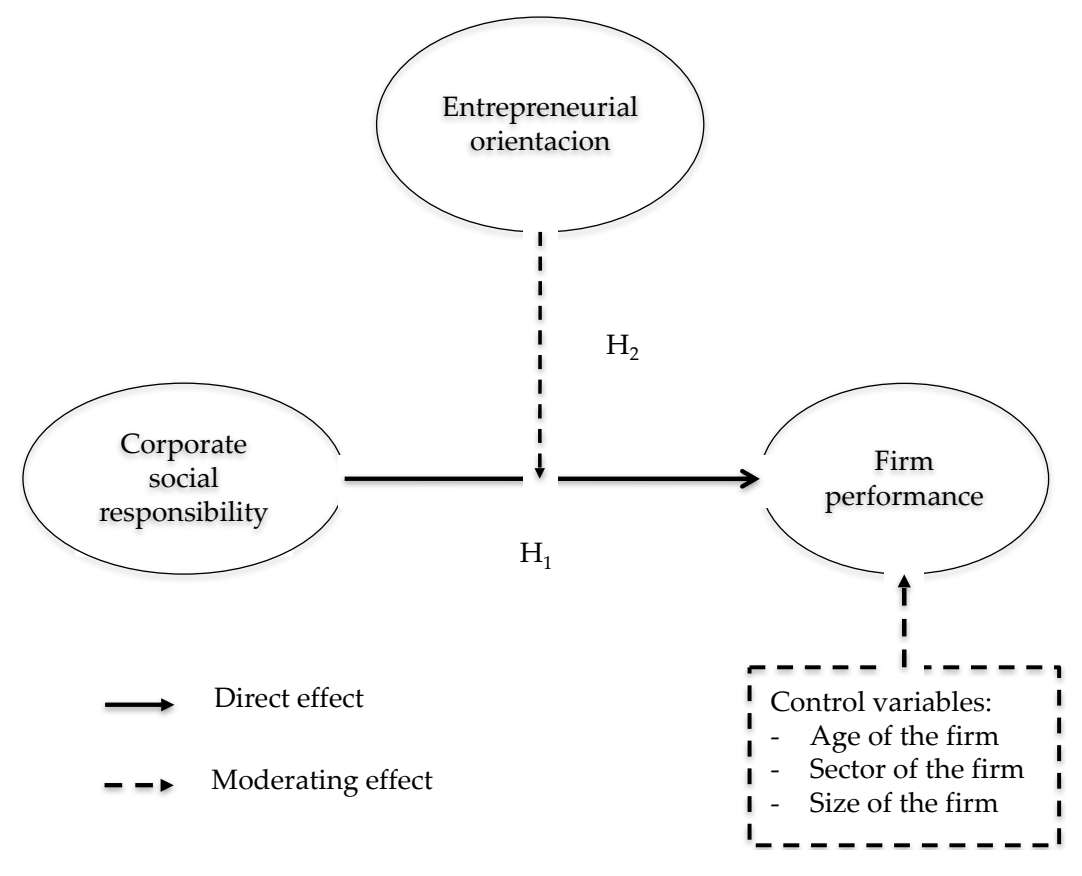

Figure 1. Proposed research model.

\section{Materials and Methods}

\subsection{Data}

Data for entrepreneurial orientation and performance were gathered from responses to a questionnaire. The questionnaire was developed in Limesurvey v. 2.5 and sent via email to the highest-ranking executives of a sample of family firms. The sample was drawn from the records of the Spanish Institute of Family Firms. The questionnaire consisted of five-point Likert-type items for the dimensions of the CSR, entrepreneurial orientation and firm performance. Data on social responsibility were gathered from the sustainability reports published by the family firms. The data collection process, which took place between November 2015 and February 2016, yielded 174 valid responses (see Table 1).

Table 1. Details of the data collection process.

\begin{tabular}{cc}
\hline Sample Size & 1045 \\
Context & Spain \\
Responses Received & 174 \\
Sampling Procedure & Simple random sampling \\
Confidence Level & $95 \%, p=q=50 \% ; \alpha=0.05$ \\
Response Rate & $16.65 \%$ \\
Sample Error & $6.79 \%$ \\
Data Collection Period & November 2015 to February 2016 \\
\hline
\end{tabular}


After collecting the data, we calculated whether the sample size was sufficient to apply partial least squares structural equation modeling (PLS-SEM). According to Barclay et al. [104], the minimum number of cases required to apply heuristic regression is 10 times the number of indicators in the scale with the largest number of formative indicators. In our case, entrepreneurial orientation was formative and was made up of three variables, which were defined by three dimensions each. It therefore had nine indicators. Accordingly, in this instance, the minimum number of cases required to apply PLS-SEM was 90. Our sample consisted of 174 cases and therefore met this requirement.

We also analyzed the statistical power of the sample using the retrospective test [105]. To do so, we used $G^{*}$ Power 3.1.9.2 [106]. Our sample of family firms had a statistical power of 0.992 (see Figure 2), exceeding the limit of 0.80, which was established by Cohen [105].

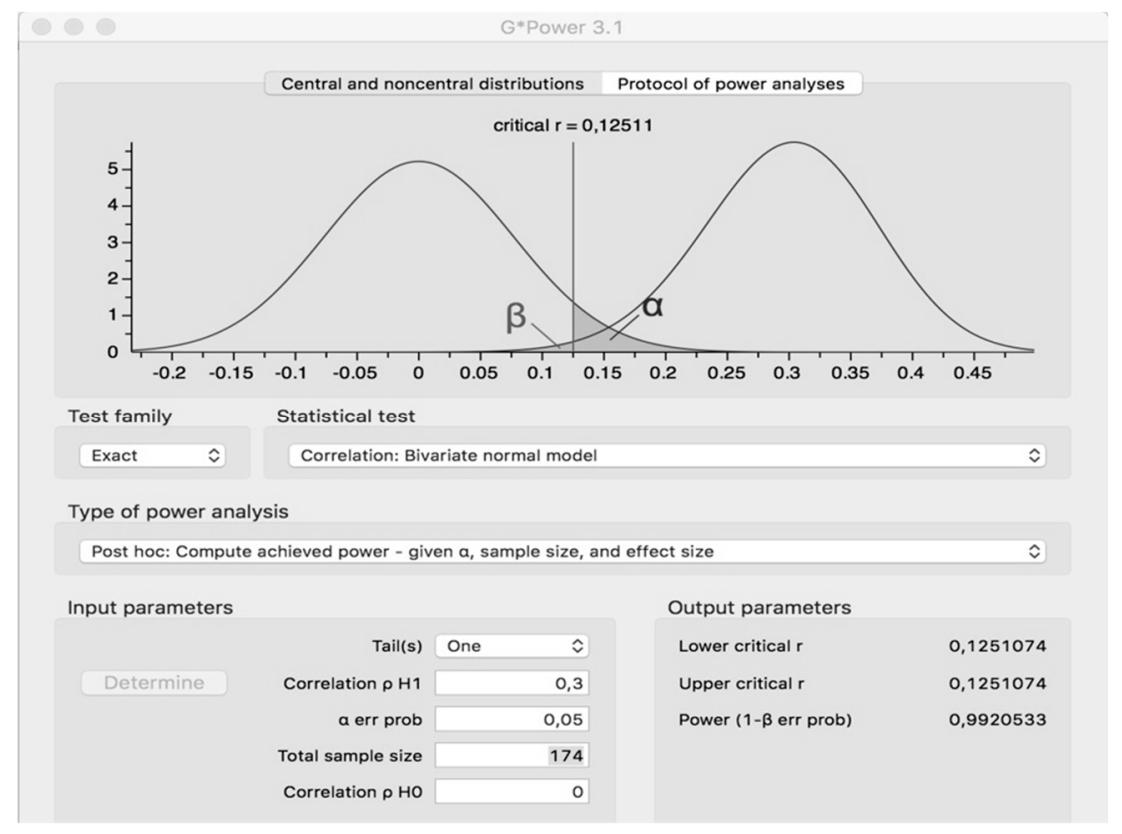

Figure 2. Statistical power of the sample.

To test our hypotheses and analyze the direct effect and the moderating effect, we used the quantitative multivariate technique of partial least squares (PLS) structural equation modeling. This method allowed us to pursue our research objectives because it was predictive in nature $[107,108]$, enabled us to observe different causal relationships [109,110], and did not impose strict requirements in terms of minimum sample size [111]. We used SmartPLS 3.2.6 [112] to conduct the PLS-SEM data analysis.

\subsection{Variable Measurement}

\subsubsection{Family Firm Performance}

In this study, we measured firm performance using the four-item scale proposed by Wiklund and Shepherd [10], Naldi et al. [85], Chirico et al. [113], Kellermanns et al. [93], and Kraus et al. [6]. The concrete expression of the items used can be seen in the questionnaire included in the Appendix A.

\subsubsection{Corporate Social Responsibility (CSR)}

Measuring CSR is taxing. To establish a measure for CSR, we first took the sustainability indices, which reflected the firm's responsible performance in relation to the firm's financial performance $[45,114]$. By releasing sustainability reports, the firm describes its CSR actions to stakeholders [4]. The sustainability reports that we analyzed in this study complied with the GRI 
format. Because we used a questionnaire with indices and data on CSR, using GRI-format reports made it easier to compare data across different firms [115]. In this study, CSR was a composite comprising three dimensions: economic, social, and environmental. This is known as the triple bottom line (TBL) $[68,116]$. The economic dimension consisted of three items, the social dimension five items, and the environmental dimension three items. The concrete expression of the items used can be seen in the questionnaire included in the Appendix A.

\subsubsection{Entrepreneurial Orientation}

To measure entrepreneurial orientation, we used the scale proposed by Miller [7] and modified by Covin and Slevin [8] and Covin and Miller [78]. This scale comprised three dimensions: innovativeness (three items), proactiveness (three items), and risk-taking (three items). The concrete expression of the items used can be seen in the questionnaire in the Appendix A.

\subsubsection{Control Variables}

The control variables were family size (number of employees), age (number of years since the company's creation) and whether the sector had been used in previous studies on family firms [117].

\section{Results}

To ensure the scales were valid and reliable, we followed the steps proposed by Barclay et al. [104]:

(1) evaluation of the measurement model, and

(2) evaluation of the structural model.

\subsection{Evaluation of the Measurement Model}

Following Roldán and Sánchez-Franco's [118] recommendations, the first step was to analyze the factor loadings, composite reliability, Cronbach's alpha, and average variance extracted (AVE). Tables 2-4 present the values for these indicators. All values for these indicators exceeded the thresholds recommended in the literature. (Carmines and Zeller [119] recommend values greater than 0.7 for the factor loadings, and Fornell and Larcker [120] recommend values greater than 0.7, 0.7, and 0.5 for the composite reliability, Cronbach's alpha, and average variance extracted (AVE), respectively.).

Table 2. Corporate social responsibility (CSR) composite and indicators.

\begin{tabular}{ccccc}
\hline Composite/Indicators & Factor Loading & Composite Reliability & Cronbach's Alpha & AVE \\
\hline CSR (second-order type a composite) & & 0.827 & 0.882 & 0.809 \\
$\begin{array}{c}\text { Economic Dimension } \\
\text { (first-order type a composite) }\end{array}$ & 0.873 & 0.880 & 0.844 & 0.760 \\
$\begin{array}{c}\text { Social Dimension } \\
\text { (first-order type a composite) }\end{array}$ & 0.893 & 0.923 & 0.914 & 0.732 \\
$\begin{array}{c}\text { Environmental Dimension } \\
\text { (first-order type a composite) }\end{array}$ & 0.908 & 0.875 & 0.836 & 0.775 \\
\hline
\end{tabular}

Table 3. Entrepreneurial orientation composite and indicators.

\begin{tabular}{|c|c|c|c|c|}
\hline Composite/Indicators & Factor Loading & Composite Reliability & Cronbach's Alpha & AVE \\
\hline Entrepreneurial Orientation (second-order type b composite) & & 0.850 & 0.733 & 0.756 \\
\hline Innovativeness (first-order type a composite) & & 0.910 & 0.851 & 0.770 \\
\hline Innovativeness 1 & 0.872 & & & \\
\hline Innovativeness 3 & 0.883 & & & \\
\hline Proactiveness (first-order type a composite) & & 0.772 & 0.765 & 0.612 \\
\hline Proactiveness 1 & 0.720 & & & \\
\hline Proactiveness 2 & 0.897 & & & \\
\hline Risk-Taking 1 & 0.775 & & & \\
\hline Risk-Taking 2 & 0.836 & & & \\
\hline Risk-Taking 3 & 0.749 & & & \\
\hline
\end{tabular}


Table 4. Business performance composite and indicators.

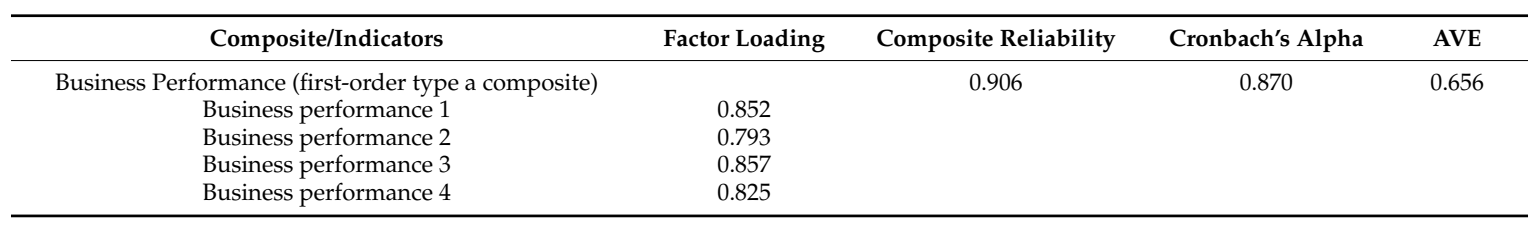

We also calculated the discriminant validity, which measures the extent to which a composite truly differs from other composites [107]. To calculate the discriminant validity, we compared the values of the square root of the average variance extracted (AVE) for each composite against the correlations between the dimensions of that composite [120]. For all dimensions of CSR and entrepreneurial orientation, the values for the square root of the AVE were greater than the corresponding correlations (Tables 5 and 6).

Table 5. Discriminant validity of the dimensions of CSR $\left(^{*}\right)$.

\begin{tabular}{cccc}
\hline & Economic Dimension & Social Dimension & Environmental Dimension \\
\hline Economic Dim. & 0.871 & & \\
Social Dim. & 0.667 & 0.855 & 0.880 \\
Environmental Dim. & 0.597 & 0.648 & \\
\hline
\end{tabular}

$\left(^{*}\right)$ The diagonal shows the square root of the AVE (in bold).

Table 6. Discriminant validity of the dimensions of entrepreneurial orientation $\left({ }^{*}\right)$.

\begin{tabular}{cccc}
\hline & Innovativeness & Proactiveness & Risk-Taking \\
\hline Innovativeness & 0.877 & & \\
Proactiveness & 0.440 & 0.782 & \\
Risk-Taking & 0.463 & 0.348 & 0.793 \\
\hline
\end{tabular}

$\left.{ }^{*}\right)$ The diagonal shows the square root of the AVE (in bold).

We also calculated the heterotrait-monotrait (HTMT) ratio for type a composites. We used the HTMT ratio to assess the discriminant validity between indicators of the same composite and between indicators of different composites. For discriminant validity to hold, the values of the HTMT ratio should be less than 0.85 [111]. The data in Table 7 show that all values were less than 0.85 .

Table 7. Heterotrait-monotrait (HTMT) ratio.

\begin{tabular}{cccc}
\hline & CSR & EO & FP \\
\hline CSR & & & \\
EO & 0.743 & & \\
FP & 0.636 & 0.702 & \\
\hline
\end{tabular}

Note: CSR—corporate social responsibility; EO—entrepreneurial orientation; $\mathrm{FP}$-firm performance.

Finally, we calculated the $\mathrm{HTMT}_{\text {inference }}$ from a bootstrapping process with 5000 subsamples. The resulting interval contained values that were smaller than 1 , confirming discriminant validity (Table 8).

Table 8. HTMT inference.

\begin{tabular}{ccccccccc}
\hline & Original Data (O) & Mean (M) & $\mathbf{5 . 0} \%$ & $\mathbf{9 5 . 0} \%$ & Mean (M) & Bias & $\mathbf{5 . 0 \%}$ & $\mathbf{9 5 . 0 \%}$ \\
\hline $\mathrm{CSR} \rightarrow$ FP & 0.636 & 0.622 & 0.275 & 0.657 & 0.412 & -0.014 & 0.277 & 0.658 \\
$\mathrm{EO} \rightarrow$ FP & 0.702 & 0.696 & 0.258 & 0.758 & 0.414 & -0.006 & 0.247 & 0.754 \\
\hline \multicolumn{2}{l}{ Note: CSR_corporate social responsibility; } & EO-entrepreneurial orientation; & FP-firm performance.
\end{tabular}


We thus confirmed that the indicators we used to measure the proposed composites were reliable and had discriminant validity.

Entrepreneurial orientation was operationalized as a second-order type b composite obtained in two stages from the scores of latent variables [121]. To validate the entrepreneurial orientation composite, we followed Diamantopoulos et al.'s [122] recommendations. The indicators for each composite did not cause problems of collinearity [123]. Problems of collinearity can arise when the variance inflation factor (VIF) is greater than or equal to 5 [124]. In this study, we did not observe any problems of collinearity (Table 9).

Table 9. Collinearity of entrepreneurial orientation.

\begin{tabular}{ccc}
\hline Factor & Loadings $(\boldsymbol{\lambda})$ & VIF \\
\hline Innovativeness & 0.478 & 1.905 \\
Proactiveness & 0.429 & 1.703 \\
Risk-Taking & 0.308 & 1.28 \\
\hline
\end{tabular}

\subsection{Evaluation of the Structural Model}

The analysis of the structural model confirmed that CSR had a positive impact on the performance of family firms. The path coefficient was 0.736 (greater than the minimum threshold of 0.2 proposed by Chin [125]). Furthermore, this effect was significant ( $t$ value 16.672 , based on $t$ (4999) one-tailed test at a significance level of $p<0.001$ ), with CSR capable of explaining $65.8 \%$ of the variance in family firm performance. The results of the analysis therefore corroborate the first hypothesis.

The moderating effect of entrepreneurial orientation was positive and significant because the path coefficient was 0.210 and the $t$ value was 5.019 (see Table 10). In addition, the moderating effect of entrepreneurial orientation caused the influence of CSR on the performance of family firms to increase, such that it was capable of explaining $70.7 \%$ of the variance (see Table 10). Finally, the effect size of the moderating effect was moderate, with an $\mathrm{f}^{2}$ value of 0.17 [126].

Table 10. Structural model.

\begin{tabular}{cccc}
\hline & $\mathbf{R}^{2}$ & $\mathbf{B}$ & T Value \\
\hline Model 1: CSR $\rightarrow$ FP & 0.658 & 0.736 & 16.672 \\
\hline Model 2: CSR $\rightarrow$ FP & \multirow{2}{*}{0.678} & 0.415 & 5.094 \\
$\mathrm{EO} \rightarrow$ FP & & 0.413 & 4.632 \\
\hline & & 0.398 & 4.657 \\
Model 3: CSR $\times$ EO $\rightarrow$ FP & \multirow{2}{*}{0.707} & 0.396 & 5.076 \\
& & 0.210 & 5.019 \\
\hline
\end{tabular}

Note: CSR—corporate social responsibility; EO—entrepreneurial orientation; FP—firm performance.

None of the control variables were relevant or significant. The coefficients were less than 0.2 , and the $t$ values were less than the recommended value (see Table 11).

Table 11. Control Variables.

\begin{tabular}{ccc}
\hline Variable & $\boldsymbol{\beta}$ & T Value \\
\hline Age & -0.099 & 0.670 \\
Sector & -0.092 & 0.525 \\
Size & -0.058 & 0.403 \\
\hline
\end{tabular}


To complete the analysis of the structural model, we calculated the goodness of fit of the model using the standardized root mean residual (SRMR), as recommended by $\mathrm{Hu}$ and Bentler [127] and Henseler et al. [111]. The SRMR was 0.07 (less than the limit of 0.08 set by Henseler et al. [111]).

\section{Discussion}

The results imply that measuring family firms' CSR through the GRI triple bottom line [63-65] is suitable because all indicators had acceptable values for reliability and validity. Therefore, consistent with the findings of previous studies, our results confirm that CSR can be considered a second-order type a composite, comprising economic, social, and environmental dimensions [64].

Consistent with findings from previous studies for larger and smaller firms [2,22,128-130], our results imply that family firms that engage in CSR activities improve their performance. This improvement in performance is substantial because CSR is capable of explaining $65.8 \%$ of the variance in the performance of family firms. This study thus fills a major gap in the literature; namely, the analysis of CSR in family firms through sustainability reports, the publication of which in itself represents a CSR action [5].

The results for the moderation model imply that entrepreneurial orientation positively moderates the influence of CSR on the performance of family firms, as demonstrated by the positive path coefficient $(0.210)$ and the increase in the variance explained to $70.7 \%$. Furthermore, entrepreneurial orientation was observed to have a moderate effect size on the relationship between CSR and the performance of family firms.

Sustainable entrepreneurship has evolved into a dynamic concept. Sustainable entrepreneurs must seek business opportunities that can lead to better economic, social, and environmental performance $[33,131,132]$. Sustainable firms must consider the social, economic, and environmental expectations of their stakeholders $[133,134]$, so they must integrate social, economic, and environmental aspects into their products and services $[135,136]$. The influence of CSR and entrepreneurial orientation on the performance of family firms is determined by purposeful actions by managers [16], which in turn are determined by the history and tradition of the firm and the nature of the family that manages the business.

The limitations of this study relate to the way CSR and entrepreneurial orientation were measured. The dimensions could have been specified independently to evaluate the effect of each dimension on performance and assess the moderating effect of each dimension of entrepreneurial orientation. Another limitation relates to our failure to consider the effect of ownership on the influence of CSR in family firms. We also overlooked the influence of context on the way each of the dimensions of CSR and entrepreneurial orientation develop.

An interesting line of research for future studies would be to compare the behavior of family and non-family firms to confirm that entrepreneurial orientation plays a moderating role and assess its effect. Occasionally, firms are too small to develop new products, projects, or services. Future studies should therefore analyze the entrepreneurial orientation derived from possible cooperation agreements. Such agreements allow firms to engage in joint learning and develop new sources of competitive advantage [137]. Another research opportunity would be to analyze young family firms that are highly innovative [17], run by women [138], and, above all, develop sustainable innovations [24]. Finally, it would be of interest to analyze the influence of corporate governance on CSR [138] and entrepreneurial orientation [139].

Author Contributions: All authors attest to making substantial, direct, intellectual contributions to this research and approve of its publication.

Conflicts of Interest: The authors declare no conflicts of interest. 


\section{Appendix A}

\section{Questionnaire}

Please answer with an $X$ in each question on a scale of 1 to 5 ; where 1 -totally disagree; 5-totally agree.

\section{Entrepreneurial Orientation}

\begin{tabular}{|c|c|c|c|c|c|}
\hline & 1 & 2 & 3 & 4 & 5 \\
\hline \multicolumn{6}{|l|}{ Innovativeness } \\
\hline \multicolumn{6}{|l|}{ My company favors a strong emphasis on R\&D, technological development and innovation. } \\
\hline \multicolumn{6}{|l|}{ In the last 5 years, my company has started new businesses or introduced new products. } \\
\hline \multicolumn{6}{|l|}{ My company has often made dramatic changes to products and services. } \\
\hline \multicolumn{6}{|l|}{ Proactiveness } \\
\hline \multicolumn{6}{|l|}{$\begin{array}{l}\text { My company typically responds to the actions initiated by competitors and rarely initiates changes in } \\
\text { their sector. }\end{array}$} \\
\hline \multicolumn{6}{|l|}{$\begin{array}{l}\text { My organization is often the first business to introduce new products or services, administrative } \\
\text { techniques, operating technologies, etc. }\end{array}$} \\
\hline \multicolumn{6}{|l|}{ My organization typically seeks to avoid competitive clashes, preferring a "live-and-let-live" posture. } \\
\hline \multicolumn{6}{|l|}{ Risk Taking } \\
\hline \multicolumn{6}{|l|}{$\begin{array}{l}\text { My company prefers to engage in investment projects with moderate risk because expectations for } \\
\text { returns are better. }\end{array}$} \\
\hline \multicolumn{6}{|l|}{$\begin{array}{l}\text { Given the dynamic environment, my company prefers to engage in investments that show incremental } \\
\text { behavior, starting with small investments and gradually increasing the commitment of resources. }\end{array}$} \\
\hline $\begin{array}{l}\text { When confronted with decision-making situations involving uncertainty, my firm typically adopts a } \\
\text { cautious, "wait-and-see" posture in order to minimize the probability of making costly decisions. }\end{array}$ & & & & & \\
\hline
\end{tabular}

\section{Corporate Social Responsibility}

Please answer with an $X$ in each question on a scale of 1 to 5; where 1-totally inadequate, and 5-fully adequate

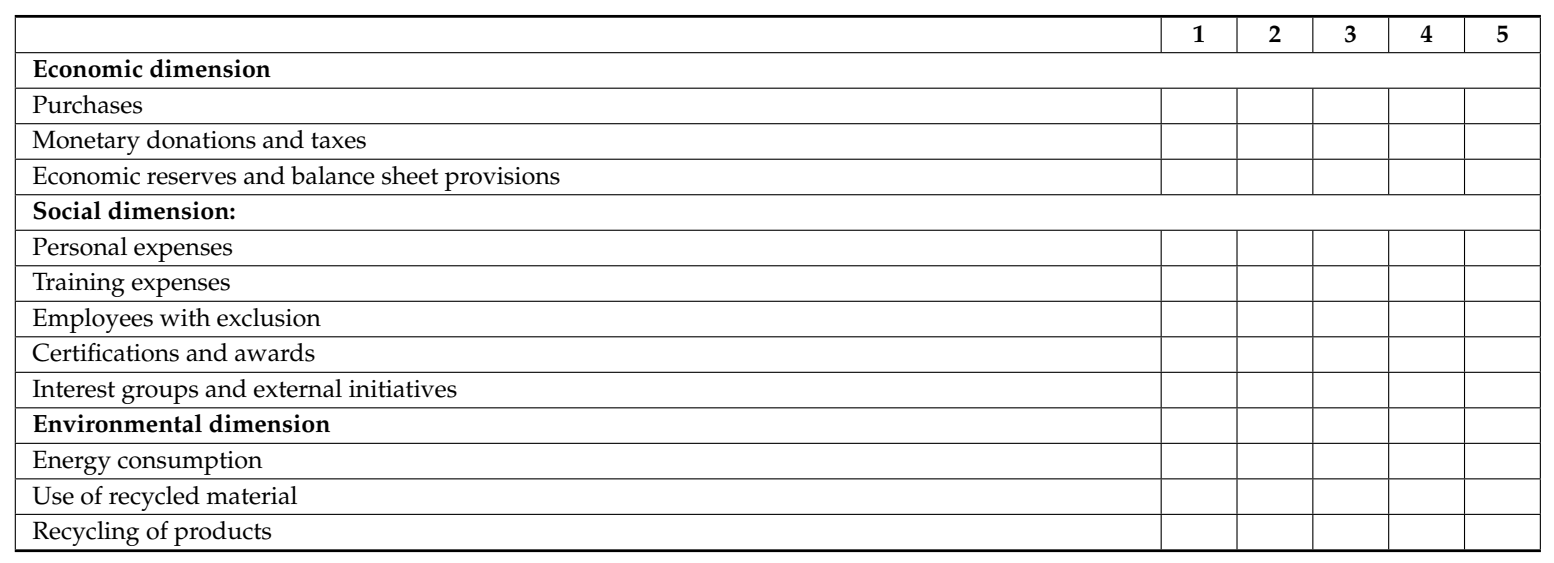

\section{Firm Performance}

Compare the following financial variables in relation to your competitors. Please answer with an $X$ in each question, on a scale of 1 to 5 ; where 1 -is much less than its competitors, and 5-much more than its competitors.

\begin{tabular}{|c|c|c|c|c|c|}
\hline & 1 & 2 & 3 & 4 & 5 \\
\hline Average annual sales growth in & & & & & \\
\hline Growth of market share in the 1 & & & & & \\
\hline Profit growth in the last year & & & & & \\
\hline Growth in the return on capital & & & & & \\
\hline
\end{tabular}

\section{References}

1. Lozano, R.; Carpenter, A.; Huisingh, D. A review of 'theories of the firm' and their contributions to Corporate Sustainability. J. Clean. Prod. 2015, 106, 430-442. [CrossRef] 
2. Herrera-Madueño, J.; Larrán-Jorge, M.; Martínez-Conesa, I.; Martínez-Martínez, D. Relationship between corporate social responsibility and competitive performance in Spanish SMEs: Empirical evidence from a stakeholders' perspective. BRQ Bus. Res. Q. 2016, 19, 55-72. [CrossRef]

3. Kramer, M.R.; Porter, M.E. Creating shared value. Harv. Bus. Rev. 2011, 89, 62-77.

4. Baviera-Puig, A.; Gómez-Navarro, T.; García-Melón, M.; García-Martínez, G. Assessing the Communication Quality of CSR reports. A Case Study on Four Spanish Food Companies. Sustainability 2015, 7, 11010-11031. [CrossRef]

5. Szczepankiewicz, E.I.; Múcko, P. CSR Reporting Practices of Polish Energy and Mining Companies. Sustainability 2016, 8, 126. [CrossRef]

6. Kraus, S.; Rigtering, J.C.; Hughes, M.; Hosman, V. Entrepreneurial orientation and the business performance of SMEs: A quantitative study from the Netherlands. Rev. Manag. Sci. 2012, 6, 161-182. [CrossRef]

7. Miller, D. The correlates of entrepreneurship in three types of firms. Manag. Sci. 1983, 29, 770-791. [CrossRef]

8. Covin, J.G.; Slevin, D.P. Strategic management of small firms in hostile and benign environments. Strateg. Manag. J. 1989, 10, 75-87. [CrossRef]

9. Zahra, S.A. Predictors and financial outcomes of corporate entrepreneurship: An exploratory study. J. Bus. Ventur. 1991, 6, 259-285. [CrossRef]

10. Wiklund, J.; Shepherd, D. Entrepreneurial orientation and small business performance: A configurational approach. J. Bus. Vent. 2005, 20, 71-91. [CrossRef]

11. Davis, J.L.; Greg Bell, R.; Tyge Payne, G.; Kreiser, P.M. Entrepreneurial orientation and firm performance: The moderating role of managerial power. Am. J. Bus. 2010, 25, 41-54. [CrossRef]

12. Frank, H.; Kessler, A.; Fink, M. Entrepreneurial Orientation and Business Performance - A Replication Study. Schmalenbach Bus. Rev. 2010, 62, 175-198.

13. Hernández-Perlines, F.; Moreno-García, J.; Yáñez-Araque, B. The mediating role of competitive strategy in international entrepreneurial orientation. J. Bus. Res. 2016, 69, 4714-4724. [CrossRef]

14. Huarng, K.H.; Hui-Kuang Yu, T. Entrepreneurship, process innovation and value creation by a non-profit SME. Manag. Decis. 2011, 49, 284-296. [CrossRef]

15. Ribeiro-Soriano, D.; Huarng, K.H. Innovation and entrepreneurship in knowledge industries. J. Bus. Res. 2013, 66, 1964-1969. [CrossRef]

16. Ribeiro-Soriano, D.; Peris-Ortiz, M. Subsidizing technology: How to succeed. J. Bus. Res. 2011, 64, $1224-1228$. [CrossRef]

17. Mas-Tur, A.; Ribeiro-Soriano, D. The level of innovation among young innovative companies: The impacts of knowledge-intensive services use, firm characteristics and the entrepreneur attributes. Serv. Bus. 2014, 8 , 51-63. [CrossRef]

18. Alvarado Herrera, A.; Bigné Alcañiz, E.; Currás Pérez, R. Theoretical perspectives for studying corporate social responsibility: A rationality-based classification. Estud. Gerenc. 2011, 27, 115-138.

19. Garcia-Castro, R.; Ariño, M.A.; Canela, M.A. Does social performance really lead to financial performance? Accounting for endogeneity. J. Bus. Ethics 2010, 92, 107-126. [CrossRef]

20. Miras-Rodríguez, M.M.; Carrasco-Gallego, A.; Escobar-Pérez, B. Are Socially Responsible Behaviors Paid Off Equally? A Cross-cultural Analysis. Corp. Soc. Res. Env. Ma. 2015, 22, 237-256. [CrossRef]

21. Battaglia, M.; Testa, F.; Bianchi, L.; Iraldo, F.; Frey, M. Corporate social responsibility and competitiveness within SMEs of the fashion industry: Evidence from Italy and France. Sustainability 2014, 6, 872-893. [CrossRef]

22. Hernández-Perlines, F.; Sánchez-Infantes, J.P. Análisis del Efecto de la Responsabilidad Social Empresarial en los Resultados Empresariales de las Micro, Pequeñas y Medianas Empresas (Mipymes)/Analysis of Effect of Corporate Social Responsibility in the Business Results of Micro, Small and Medium-Sized Enterprises (MSMEs)/ Análise do Efeito da Responsabilidade Social das Resultados do Negócio nas Micro, Pequenas e Médias Empresas (MPMEs). Rev. Glob. Compet. Gob. 2016, 10, 110-123.

23. Urbano, D.; Toledano, N.; Ribeiro-Soriano, D. Socio-cultural factors and transnational entrepreneurship: A multiple case study in Spain. Int. Small Bus. J. 2011, 29, 119-134. [CrossRef]

24. Klein Woolthuis, R.J. Sustainable entrepreneurship in the Dutch construction industry. Sustainability 2010, 2, 505-523. [CrossRef]

25. Preston, L.E.; O’Bannon, D.P. The corporate social-financial performance relationship: A typology and analysis. Bus. Soc. 1997, 36, 419-429. [CrossRef] 
26. Andersen, M.L.; Dejoy, J.S. Corporate social and financial performance: The role of size, industry, risk, R\&D and advertising expenses as control variables. Bus. Soc. Rev. 2011, 116, 237-256.

27. McWilliams, A.; Siegel, D. Corporate social responsibility: A theory of the firm perspective. Acad. Manag. Rev. 2001, 26, 117-127.

28. Schumpeter, J.A. The Theory of Economic Development: An Inquiry into Profits, Capital, Credit, Interest, and the Business Cycle; Transaction Publishers: London, UK, 1934.

29. Kirzner, I.M. Competition and Entrepreneurship; University of Chicago Press: Chicago, IL, USA, 1973.

30. Cohen, B.; Winn, M. Market imperfections, opportunity and sustainable entrepreneurship. J. Bus. Vent. 2007, 22, 29-49. [CrossRef]

31. Dean, T.J.; McMullen, J.S. Toward a theory of sustainable entrepreneurship: Reducing environmental degradation through entrepreneurial action. J. Bus. Vent. 2007, 27, 50-76. [CrossRef]

32. Binder, J.; Belz, F.M. Sustainable entrepreneurship: A convergent process model. Bus. Strateg. Environ. 2014, 15, 402-415.

33. Thompson, N.; Kiefer, K.; York, J.G. Distinctions not Dichotomies: Exploring Social, Sustainable, and Environmental Entrepreneurship. In Social and Sustainable Entrepreneurship (Advances in Entrepreneurship, Firm Emergence and Growth); Lumpkin, G.T., Katz, J.A., Eds.; Emerald Group Publishing Limited: Bingley, UK, 2011; Volume 13, pp. 201-229.

34. Larson, A.L. Sustainable innovation through an entrepreneurship lens. Bus. Strateg. Environ. 2000, 9, $304-317$. [CrossRef]

35. Dyllick, T.; Hockerts, K. Beyond the business case for corporate sustainability. Bus. Strateg. Environ. 2002, 11, 130-141. [CrossRef]

36. Young, W.; Tilley, F. Can businesses move beyond efficiency? The shift toward effectiveness and equity in the corporate sustainability debate. Bus. Strateg. Environ. 2006, 15, 402-415. [CrossRef]

37. Lepak, D.P.; Smith, K.G.; Taylor, M.S. Value Creation and Value Capture: A Multilevel Perspective. Acad. Manag. Rev. 2007, 32, 180-194. [CrossRef]

38. Belz, F.M. Shaping the future: Sustainable innovation and entrepreneurship. Soc. Bus. 2013, 3, 311-324. [CrossRef]

39. Hall, J.; Daneke, G.; Lenox, M. Sustainable development and entrepreneurship: Past contributions and future directions. J. Bus. Vent. 2010, 25, 439-448. [CrossRef]

40. Corona, J.; Del Sol, I. La Empresa Familiar en España (2015); Instituto de la Empresa Familiar: Barcelona, Spain, 2016. Available online: http://www.iefamiliar.com/upload/documentos/ubhiccx9o8nnzc7i.pdf (accessed on 6 May 2017).

41. Lu, W.; Chau, K.W.; Wang, H.; Pan, W. A decade's debate on the nexus between corporate social and corporate financial performance: A critical review of empirical studies 2002-2011. J. Clean. Prod. 2014, 79, 195-206. [CrossRef]

42. Barnard, C. The Functions of the Executive; Harvard University Press: Cambridge, MA, USA, 1938.

43. Kreps, T.J. Measurement of the social performance of business. Ann. Am. Acad. Polit. Soc. Sci. 1962, 343, 20-31. [CrossRef]

44. Freeman, R.E. Strategic Management: A Stakeholders Approach; Pitman: Boston, MA, USA, 1984.

45. Margolis, J.D.; Walsh, J.P. Misery loves companies: Rethinking social initiatives by business. Admin. Sci. $Q$. 2003, 48, 268-305. [CrossRef]

46. Orlitzky, M.; Schmidt, F.L.; Rynes, S.L. Corporate Social and Financial Performance: A Meta-Analysis. Organ. Stud. 2003, 24, 403-441. [CrossRef]

47. Wu, M.L. Corporate Social Performance, Corporate Financial Performance, and Firm Size: A Meta-Analysis. J. Am. Acad. Bus. 2006, 8, 163-171.

48. De Massis, A. Family Involvement and Procedural Justice Climate among Nonfamily Managers: The Effects of Affect, Social Identities, Trust, and Risk of Non-Reciprocity. Entrep. Theory Pract. 2012, 36, 1227-1234. [CrossRef]

49. Dyer, W.G. The Family: The Missing Variable in Organizational Research. Entrep. Theory Pract. 2003, 27, 401-416. [CrossRef]

50. Zellweger, T. Time Horizon, Costs of Equity Capital, and Generic Investment Strategies of Firms. Fam. Bus. Rev. 2007, 20, 1-15. [CrossRef] 
51. Long, R.G.; Mathews, K.M. Ethics in the Family Firm: Cohesion through Reciprocity and Exchange. Bus. Ethics Q. 2011, 21, 287-308. [CrossRef]

52. Kotlar, J.; De Massis, A. Goal Setting in Family Firms: Goal Diversity, Social Interactions, and Collective Commitment to Family-Centered Goals. Entrep. Theory Pract. 2013, 37, 1263-1288. [CrossRef]

53. Reid, R.S.; Adams, J.S. Human resource management-A survey of practices within family and non-family firms. J. Eur. Ind. Train. 2001, 25, 310-320. [CrossRef]

54. De Kok, J.M.P.; Uhlaner, L.M.; Thurik, A.R. Professional HRM Practices in Family Owned-Managed Enterprises. J. Small Bus. Manag. 2006, 44, 441-460. [CrossRef]

55. Colombo, M.G.; De Massis, A.; Piva, E.; Rossi-Lamastra, C.; Wright, M. Sales and Employment Changes in Entrepreneurial Ventures with Family Ownership: Empirical Evidence from High-Tech Industries. J. Small Bus. Manag. 2014, 52, 226-245. [CrossRef]

56. Berrone, P.; Cruz, C.; Gomez-Mejia, L.R.; Larraza-Kintana, M. Socioemotional Wealth and Corporate Responses to Institutional Pressures: Do Family-Controlled Firms Pollute Less? Admin. Sci. Q. 2010, 55, 82-113. [CrossRef]

57. Gémar, G.; Espinar, D. Communication about corporate social responsibility practices and return on equity. Revista de Empresa Familiar 2015, 5, 7-17.

58. De la Cruz Déniz Déniz, M.; Cabrera Suárez, K. Corporate Social Responsibility and Family Business in Spain. J. Bus. Ethics 2005, 56, 27-41. [CrossRef]

59. Niehm, L.S.; Swinney, J.; Miller, N.J. Community Social Responsibility and Its Consequences for Family Business Performance. J. Small Bus. Manag. 2008, 46, 331-350. [CrossRef]

60. Ding, S.; Wu, Z. Family Ownership and Corporate Misconduct in U.S. Small Firms. J. Bus. Ethics 2014, 123, 183-195. [CrossRef]

61. Dyer, W.G.; Whetten, D.A. Family Firms and Social Responsibility. Entrep. Theory Pract. 2006, 30, 785-802. [CrossRef]

62. Hirigoyen, G.; Poulain-Rehm, T. The corporate social responsibility of family businesses: An international approach. Int. J. Financ. Stud. 2014, 2, 240-265. [CrossRef]

63. Gamerschlag, R.; Möller, K.; Verbeeten, F. Determinants of voluntary CSR disclosure: Empirical evidence from Germany. Rev. Manag. Sci. 2011, 5, 233-262. [CrossRef]

64. Campopiano, G.; De Massis, A. Corporate Social Responsibility Reporting: A Content Analysis in Family and Non-family Firms. J. Bus. Ethics 2015, 129, 511-534. [CrossRef]

65. Chen, L.; Feldmann, A.; Tang, O. The relationship between disclosures of corporate social performance and financial performance: Evidences from GRI reports in manufacturing industry. Int. J. Prod. Econ. 2015, 170, 445-456. [CrossRef]

66. Martín-Castejón, P.J.; Aroca-López, B. Corporate social responsibility in family SMEs: A comparative study. Eur. J. Fam. Bus. 2016, 6, 21-31. [CrossRef]

67. Martínez-Campillo, A.; Cabeza-García, L.; Marbella-Sánchez, F. Responsabilidad social corporativa y resultado financiero: Evidencia sobre la doble dirección de la causalidad en el sector de las Cajas de Ahorros/Corporate social responsibility and results: Evidence of two-way causality in the Savings Bank sector. Cuad. Econ. Dir. Empres. 2013, 16, 54-68.

68. Li, F.; Li, T.; Minor, D. CEO power, corporate social responsibility, and firm value: A test of agency theory. Int. J. Manag. Fin. 2016, 12, 611-628. [CrossRef]

69. Pan, X.; Sha, J.; Zhang, H.; Ke, W. Relationship between corporate social responsibility and financial performance in the mineral Industry: Evidence from Chinese mineral firms. Sustainability 2014, 6, 4077-4101. [CrossRef]

70. Pineiro-Chousa, J.; Vizcaíno-González, M.; López-Cabarcos, M. Reputation, Game Theory and Entrepreneurial Sustainability. Sustainability 2016, 8, 1196. [CrossRef]

71. Elkington, J. Towards the sustainable corporation: Win-win-win business strategies for sustainable development. Calif. Manag. Rev. 1994, 36, 90-100. [CrossRef]

72. Pope, J.; Annandale, D.; Morrison-Saunders, A. Conceptualising sustainability assessment. Environ. Impact Assess. 2004, 24, 595-616. [CrossRef]

73. Radomska, J. The concept of sustainable strategy implementation. Sustainability 2015, 7, 15847-15856. [CrossRef]

74. Galbreath, J. Building corporate social responsibility into strategy. Eur. Bus. Rev. 2009, 21, 109-127. [CrossRef] 
75. Van Marrewijk, M.; Werre, M. Multiple levels of corporate sustainability. J. Bus. Ethics 2003, 44, 107-119. [CrossRef]

76. Covin, J.G.; Slevin, D.P. A conceptual model of entrepreneurship as firm behavior. Entrep. Theory Pract. 1991, $16,7-25$.

77. Rauch, A.; Wiklund, J.; Lumpkin, G.T.; Frese, M. Entrepreneurial orientation and business performance: An assessment of past research and suggestions for the future. Entrep. Theory Pract. 2009, 33, 761-787. [CrossRef]

78. Covin, J.G.; Miller, D. International entrepreneurial orientation: Conceptual considerations, research themes, measurement issues, and future research directions. Entrep. Theory Pract. 2014, 38, 11-44. [CrossRef]

79. Engelen, A.; Gupta, V.; Strenger, L.; Brettel, M. Entrepreneurial orientation, firm performance, and the moderating role of transformational leadership behaviors. J. Manag. 2015, 41, 1069-1097. [CrossRef]

80. Huarng, K.H.; Ribeiro-Soriano, D.E. Developmental management: Theories, methods, and applications in entrepreneurship, innovation, and sensemaking. J. Bus. Res. 2014, 67, 657-662. [CrossRef]

81. George, B.A.; Marino, L. The epistemology of entrepreneurial orientation: Conceptual formation, modeling, and operationalization. Entrep. Theory Pract. 2011, 35, 989-1024. [CrossRef]

82. Miller, D.; Friesen, P. Strategy making and environment: The third link. Strateg. Manag. J. 1983, 4, $221-235$. [CrossRef]

83. Kropp, F.; Lindsay, N.J.; Shoham, A. Entrepreneurial, market, and learning orientations and international entrepreneurial business venture performance in South African firms. Int. Market. Rev. 2006, 23, 504-523. [CrossRef]

84. Chandra, Y.; Styles, C.; Wilkinson, I. The recognition of first time international entrepreneurial opportunities: Evidence from firms in knowledge-based industries. Int. Market. Rev. 2009, 26, 30-61. [CrossRef]

85. Naldi, L.; Nordqvist, M.; Sjöberg, K.; Wiklund, J. Entrepreneurial orientation, risk taking, and performance in family firms. Fam. Bus. Rev. 2007, 20, 33-47. [CrossRef]

86. Casillas, J.C.; Moreno, A.M. The relationship between entrepreneurial orientation and growth: The moderating role of family involvement. Entrep. Reg. Dev. 2010, 22, 265-291. [CrossRef]

87. Nordqvist, M.; Melin, L. Entrepreneurial families and family firms. Entrep. Reg. Dev. 2010, 22, $211-239$. [CrossRef]

88. Weismeier-Sammer, D. Entrepreneurial behavior in family firms: A replication study. J. Fam. Bus. Strateg. 2011, 2, 128-138. [CrossRef]

89. Zellweger, T.; Sieger, P. Entrepreneurial orientation in long-lived family firms. Small Bus. Econ. 2012, 38, 67-84. [CrossRef]

90. Cruz, C.; Nordqvist, M. Entrepreneurial orientation in family firms: A generational perspective. Small Bus. Econ. 2012, 38, 33-49. [CrossRef]

91. Vecchiarini, M.; Mussolino, D. Determinants of entrepreneurial orientation in family-owned healthcare organizations. Int. J. Healthc. Manag. 2013, 6, 237-251. [CrossRef]

92. Garcés-Galdeano, L.; Larraza-Kintana, M.; García-Olaverri, C.; Makri, M. Entrepreneurial orientation in family firms: The moderating role of technological intensity and performance. Int. Entrep. Manag. J. 2016, 12, 27-45. [CrossRef]

93. Kellermanns, F.W.; Eddleston, K.A.; Sarathy, R.; Murphy, F. Innovativeness in family firms: A family influence perspective. Small Bus. Econ. 2012, 38, 85-101. [CrossRef]

94. Schepers, J.; Voordeckers, W.; Steijvers, T.; Laveren, E. The entrepreneurial orientation-performance relationship in private family firms: The moderating role of socioemotional wealth. Small Bus. Econ. 2014, 43, 39-55. [CrossRef]

95. Zahra, S.A.; Covin, J.G. Contextual influences on the corporate entrepreneurship-performance relationship: A longitudinal analysis. J. Bus. Vent. 1995, 10, 43-58. [CrossRef]

96. Khedhaouria, A.; Gurău, C.; Torrès, O. Creativity, self-efficacy, and small-firm performance: The mediating role of entrepreneurial orientation. Small Bus. Econ. 2015, 44, 485-504. [CrossRef]

97. Alfin, R. The role of entrepreneurial orientation as a mediating effect of the characteristics and culture of small-scale industries on the performance of small-scale industries in Pasuruan. Int. J. Appl. Bus. Econ. Res. 2015, 12, 219-227.

98. Roxas, B.; Chadee, D. Effects of formal institutions on the performance of the tourism sector in the Philippines: The mediating role of entrepreneurial orientation. Tour. Manag. 2013, 37, 1-12. [CrossRef] 
99. Rosenbusch, N.; Rauch, A.; Bausch, A. The mediating role of entrepreneurial orientation in the task environment-performance relationship: A meta-analysis. J. Manag. 2013, 39, 633-659. [CrossRef]

100. Luu, T. Psychological contract and knowledge sharing: CSR as an antecedent and entrepreneurial orientation as a moderator. Corp. Com. Int. J. 2016, 21, 2-19. [CrossRef]

101. Celec, R.; Globocnik, D.; Kruse, P. Resources, capabilities, export performance and the moderating role of entrepreneurial orientation in the context of SMEs. Eur. J. Int. Manag. 2014, 8, 440-464. [CrossRef]

102. Wales, W.J.; Parida, V.; Patel, P.C. Too much of a good thing? Absorptive capacity, firm performance, and the moderating role of entrepreneurial orientation. Strateg. Manag. J. 2013, 34, 622-633. [CrossRef]

103. Mehdivand, M.; Zali, M.R.; Madhoshi, M.; Kordnaeij, A. Intellectual Capital and Nano-Businesses Performance: The Moderating Role of Entrepreneurial Orientation. Eur. J. Econ. Fin. Admin. Sci. 2012, 52, 147-162.

104. Barclay, D.; Higgins, C.; Thompson, R. The partial least squares (PLS) approach to causal modeling: Personal computer adoption and use as an illustration. Technol. Stud. 1995, 2, 285-309.

105. Cohen, J. A power primer. Psychol. Bull. 1992, 112, 155-159. [CrossRef] [PubMed]

106. Faul, F.; Erdfelder, E.; Buchner, A.; Lang, A.G. Statistical power analyses using G* Power 3.1: Tests for correlation and regression analyses. Behav. Res. Methods 2009, 41, 1149-1160. [CrossRef] [PubMed]

107. Hair Jr, J.F.; Sarstedt, M.; Hopkins, L.G.; Kuppelwieser, V. Partial least squares structural equation modeling (PLS-SEM): An emerging tool in business research. Eur. Bus. Rev. 2014, 26, 106-121. [CrossRef]

108. Sarstedt, M.; Ringle, C.M.; Smith, D.; Reams, R.; Hair, J.F. Partial least squares structural equation modeling (PLS-SEM): A useful tool for family business researchers. J. Fam. Bus. Strateg. 2014, 5, 105-115. [CrossRef]

109. Jöreskog, K.G.; Wold, H.O. Systems under Indirect Observation: Causality, Structure, Prediction; North Holland: Amsterdam, The Netherlands, 1982.

110. Astrachan, C.B.; Patel, V.K.; Wanzenried, G. A comparative study of CB-SEM and PLS-SEM for theory development in family firm research. J. Fam. Bus. Strateg. 2014, 5, 116-128. [CrossRef]

111. Henseler, J.; Ringle, C.M.; Sarstedt, M. A new criterion for assessing discriminant validity in variance-based structural equation modeling. J. Acad. Market. Sci. 2015, 43, 115-135. [CrossRef]

112. Ringle, C.M.; Wende, S.; Becker, J.M. Smart PLS 3. 2015; Boenningstedt: SmartPLS GmbH. Available online: http:/ / www.smartpls.com (accessed on 6 May 2017).

113. Chirico, F.; Sirmon, D.G.; Sciascia, S.; Mazzola, P. Resource orchestration in family firms: Investigating how entrepreneurial orientation, generational involvement, and participative strategy affect performance. Strateg. Entrep. J. 2011, 5, 307-326. [CrossRef]

114. Griffin, J.J.; Mahon, J.F. The corporate social performance and corporate financial performance debate: Twenty-five years of incomparable research. Bus. Soc. 1997, 36, 5-31. [CrossRef]

115. Schadewith, H.; Niskala, M. Communication via Responsibility Reporting and its Effect on Firm Value in Finland. Corp. Soc. Responsib. Environ. Manag. 2010, 17, 96-106.

116. Chang, D.S.; Kuo, L.C.R. The effects of sustainable development on firms' financial performance-an empirical approach. Sustain. Dev. 2008, 16, 365-380. [CrossRef]

117. Chrisman, J.J.; Chua, J.H.; Sharma, P. Trends and directions in the development of a strategic management theory of the family firm. Entrep. Theory Pract. 2005, 29, 555-576. [CrossRef]

118. Roldán, J.L.; Sánchez-Franco, M.J. Variance-based structural equation modeling: Guidelines for using partial least squares in information systems research. In Research Methodologies, Innovations and Philosophies in Software Systems Engineering and Information Systems; Mora, M., Gelman, O., Steenkamp, A., Raisinghani, M.S., Eds.; IGI Global: Hershey, PA, USA, 2012; pp. 193-221.

119. Carmines, E.G.; Zeller, R.A. Reliability and Validity Assessment; Sage Publications: Thousand Oaks, CA, USA, 1979; Volume 17.

120. Fornell, C.; Larcker, D.F. Evaluating structural equation models with unobservable variables and measurement error. J. Mark. Res. 1981, 18, 39-50. [CrossRef]

121. Wright, R.T.; Campbell, D.E.; Thatcher, J.B.; Roberts, N. Operationalizing multidimensional constructs in structural equation modeling: Recommendations for IS research. Com. Assoc. Inf. Sys. 2012, 30, 367-412.

122. Diamantopoulos, A.; Riefler, P.; Roth, K.P. Advancing formative measurement models. J. Bus. Res. 2008, 61, 1203-1218. [CrossRef]

123. Diamantopoulos, A.; Winklhofer, H.M. Index construction with formative indicators: an alternative to scale development. J. Mark. Res. 2001, 38, 269-277. [CrossRef] 
124. Kleinbaum, D.G.; Kupper, L.L.; Muller, K.E.; Nizam, A. Applied Regression Analysis and Other Multivariable Methods; PWS-Kent Publishing Co.: Boston, MA, USA, 1988; pp. 341-386.

125. Chin, W.W. The partial least squares approach to structural equation modeling. In Modern Methods for Business Research; Marcoulides, G.A., Ed.; Lawrence Erlbaum Associates Publishers: Mahwah, NJ, USA, 1998; pp. 295-336.

126. Chin, W.W. How to Write up and Report PLS Analyses; Springer: Berlin, Germany, 2010.

127. Hu, L.T.; Bentler, P.M. Fit indices in covariance structure modeling: Sensitivity to under parameterized model misspecification. Psychol. Methods 1998, 3, 424-453. [CrossRef]

128. Surroca, J.; Tribó, J.A.; Waddock, S. Corporate responsibility and financial performance: The role of intangible resources. Strateg. Manag. J. 2010, 31, 463-490. [CrossRef]

129. Perrini, F.; Russo, A.; Tencati, A.; Vurro, C. Deconstructing the relationship between corporate social and financial performance. J. Bus. Ethics 2011, 102, 59-76. [CrossRef]

130. Martínez-Ferrero, J.; Rodríguez-Ariza, L.; García-Sánchez, I.M. Corporate social responsibility as an entrenchment strategy, with a focus on the implications of family ownership. J. Clean. Prod. 2016, 135, 760-770. [CrossRef]

131. Cohen, B.; Smith, B.; Mitchell, R. Toward a sustainable conceptualization of dependent variables in entrepreneurship research. Bus. Strateg. Environ. 2008, 17, 107-119. [CrossRef]

132. Hahn, T.; Figge, F.; Pinkse, J.; Preuss, L. Trade-offs in corporate sustainability: You can't have your cake and eat it. Bus. Strateg. Environ. 2010, 19, 217-229. [CrossRef]

133. Choi, D.; Gray, E. The venture development processes of "sustainable" entrepreneurs. Manag. Res. News 2008, 8, 558-569. [CrossRef]

134. Keskin, D.; Carel, D.J.; Molenaar, N. Innovation process of new ventures driven by sustainability. J. Clean. Prod. 2013, 45, 50-60. [CrossRef]

135. Berchicci, L.; Bodewes, W. Bridging environmental issues with new product development. Bus. Strateg. Environ. 2005, 14, 272-285. [CrossRef]

136. Belz, F.M.; Peattie, K. Sustainability Marketing: A Global Perspective; Wiley: Chichester, UK, 2012.

137. Benavides-Espinosa, M.; Ribeiro-Soriano, D. Cooperative learning in creating and managing joint ventures. J. Bus. Res. 2014, 67, 648-655. [CrossRef]

138. Dienes, D.; Velte, P. The Impact of Supervisory Board Composition on CSR Reporting. Evidence from the German Two-Tier System. Sustainability 2016, 8, 63. [CrossRef]

139. García-Sánchez, E.; García-Morales, V.J.; Martín-Rojas, R. Analysis of the influence of the environment, stakeholder integration capability, absorptive capacity, and technological skills on organizational performance through corporate entrepreneurship. Int. Entrep. Manag. J. 2017, 13, 1-33. [CrossRef] 